\title{
GAMBAR ANIMASI SEBAGAI MEDIA PEMBELAJARAN IPS DI SEKOLAH DASAR
}

\author{
Zulaikhah \\ Dosen FAI Unwahas Semarang
}

\begin{abstract}
Abstrak
Media gambar animasi yang berupa film atau video merupakan media yang digunakan untuk mengkomunikasikan pesan pada siswa pada pembelajaran IPS meliputi bentuk-bentuk atau unsur-unsur verbal (teks atau kata-kata), sound/suara, juga unsur-unsur grafik (gambar dan yang sejenis gambar) seperti drawing/lukisan, chart, gambar/foto warna dan sejenisnya, poster dan kartun, dimana sumber-sumber media tersebut bisa berasal dari textbook, bahan-bahan referensi, koran, jurnal, baik yang dibuat sendiri oleh guru, ahli media maupun siswa. Media gambar animasi termasuk media yang masih jarang dipakai dalam pembelajaran IPS. Hal ini dikarenakan guru belum terbiasa menggunakan dan mengilustrasikan materi dengan gambar, padahal jika gambar animasi dibuat dan disajikan sesuai dengan persyaratan yang baik, tentu akan menambah semangat dan motivasi siswa dalam mengikuti proses pembelajaran. Media gambar animasi, dapat memberi gagasan dan dorongan kepada guru dalam mengajar anak-anak Sekolah Dasar atau Madrasah Ibtidaiyah agar lebih kreatif dalam mengembangkan alat peraga agar para murid menjadi senang belajar.
\end{abstract}

Kata Kunci: gambar animasi, media pembelajaran

\section{A. Pendahuluan}

Dalam proses pembelajaran siswa sering dijadikan kambing hitam ketika hasil pembelajaran tidak dapat mencapai target seperti yang diinginkan. Siswa dianggap malas, tidak mau belajar, kurang memperhatikan pelajaran, dan sebagainya. Hal semacam ini sering terjadi. Tetapi apakah pendidik telah melakukan introspeksi diri mengenai bagaimana kinerjanya? Bagaimana usahanya dalam meningkatkan proses pembelajaran? Dan bagaimana membantu siswa dalam meningkatkan prestasi?

Sebenarnya, ada banyak cara untuk meningkatkan belajar siswa, salah satunya adalah dengan memanfaatkan media pembelajaran. Dengan memanfaatkan berbagai media, proses pembelajaran bisa menjadi lebih menarik dan menyenangkan. 


\section{B. Media dan Peranannya dalam Pembelajaran}

Media berasal dari kata medium yang berarti sarana komunikasi. Medium sendiri berasal dari bahasa Latin yang berarti 'between' yaitu perantara/antara, artinya membawa informasi dari sumber/pengirim kepada penerima. ${ }^{1}$ Media merupakan semua bentuk dan saluran yang digunakan dalam proses penyampaian informasi.2 Pengirim dan penerima bisa dalam bentuk orang atau lembaga, dan media tersebut dapat berupa alatalat elektronik, gambar, buku, dan sebagainya.

Secara luas, media adalah semua manusia, materi, dan kejadian yang membangun kondisi yang membuat siswa mampu memperoleh pengetahuan, keterampilan dan sikap. ${ }^{3}$ Ini sejalan dengan pendapat Ely, yakni: "A medium, broadly conceived is any person, material, or event that establishes conditions which enable the learner to acquire knowledge, skill, and attitudes. In this sense, the teacher, the textbook, and the school environment are media".4

Media merupakan orang, bahan dan peristiwa yang membangun kondisi yang memungkinkan siswa untuk mendapatkan pengetahuan, keterampilan, atau sikap yang dalam konteks ini, guru, buku teks, dan lingkungan sekolah merupakan media. Media merupakan pengantar informasi antara sumber dan penerima. Seperti televisi, film, foto, radio, hasil rekaman, audio, gambar yang diproyeksikan, bahan-bahan cetak, dan sejenisnya. Ini disebut media komunikasi dan apabila media tersebut membawa pesan atau informasi pembelajaran maka media tersebut disebut media pembelajaran.

Kemp dan Dayton menjelaskan media pembelajaran sebagai berikut:

Instructional media also make use at the power of pictures, words, and sounds to compel attention, to help an audience understand ideas and acquire information to complex for verbal explanation alone, and to help overcome the limitation of time, size, and space.

Maksudnya, media pembelajaran adalah penggunaan gambar, tulisan, dan suara untuk meningkatkan perhatian, membawa siswa memahami ide dan mendapatkan informasi yang sangat komplek yang memerlukan penjelasan tersendiri. Media dapat mengatasi keterbatasan waktu, ukuran dan tempat. Azhar Arsyad menyatakan bahwa

1 Newby, Instructional technology for teaching and learning: Designing instruction, integrating computer, and using media, (New Jersey: Prentice Hall, 2000), hlm. 100

${ }^{2}$ Atwi Suparman, Desain instruksional, (Jakarta: PAC-PPAI Depdiknas, 2001), hlm. 187

3 Azhar Arsyad, Media pengajaran, J(akarta: Raja Grasindo Persada, 2004), hlm. 74 hlm. 241

4 Ely, D.P. \& Gerlach, V.G., Teaching \& Media: A systematic to Approach, (New Jersey: Prentice Hall, 1980),

5 Kemp, J.E., \& Dayton, D. K., Planning and producing instructional media, (New York: Harper \& Row Publisher Combridge, 1985), hlm. 3 
media pembelajaran adalah komponen sumber belajar atau sarana fisik yang mengandung materi. ${ }^{6}$

Jadi, media pembelajaran merupakan segala sesuatu yang dapat digunakan dan dimanfaatkan untuk menyalurkan pesan dan informasi pembelajaran, sehingga dapat merangsang perhatian, minat, pikiran dan perasaan siswa dalam kegiatan pembelajaran untuk mencapai kompetensi yang diharapkan.

Media memiliki banyak peranan, diantaranya adalah: (a) memperbesar benda yang sangat kecil, (b) menghadirkan benda yang jauh dari siswa, (c) menyajikan peristiwa yang komplek, rumit, yang berlangsung sangat cepat atau lambat menjadi lebih sistematis dan sederhana, (d) menampung siswa dalam jumlah besar untuk mempelajari materi dalam waktu yang sama, (e) menyajikan benda berbahaya ke hadapan siswa, (f) meningkatkan daya tarik dan minat serta perhatian siswa, dan (g) meningkatkan sistematika pengajaran. $^{7}$

Media pembelajaran juga digunakan oleh guru dan siswa untuk: (a) menyajikan materi dengan cara siswa mengasimilasi agar media mudah terbaca, (b) memberikan bahan dengan cara terpisah dari guru, yang memungkinkan siswa belajar sesuai dengan kecepatan dan porsinya, (c) memberikan bahan kepada siswa dengan cara siswa mengalami sendiri dengan berbagai inderanya (melihat gambar, membaca teks dan mendengarkan deskripsi secara verbal), (d) memberikan pengalaman kepada siswa yang bisa diulang-ulang dan bervariasi, (e) menarik dan memelihara perhatian siswa terhadap materi, (f) menyajikan materi yang tidak bisa dialami oleh siswa, dan (g) mengakomodir berbagai ukuran pendengar. 8

Media menjadikan pembelajaran lebih bermakna karena memiliki kelebihankelebihan: penyampaian materi bisa lebih baku, lebih menarik, belajar lebih interaktif melalui penerapan teori belajar yang telah diterima, lama waktu untuk pembelajaran bisa dikurangi, kualitas belajar lebih meningkat, pembelajaran dapat disampaikan sesuai keperluan, sikap positif siswa terhadap materi yang mereka pelajari dan proses belajar tersebut dapat ditingkatkan, dan peran guru dapat bergeser ke arah yang lebih positif. ${ }^{9}$

Peran media pembelajaran sangat penting dalam mendukung keberhasilan pembelajaran. Media merupakan sesuatu yang integral dalam pembelajaran karena dasar kebijakan dalam pemilihan, pengembangan maupun pemanfaatan media tidak terlepas dari pengetahuan ini.

\footnotetext{
${ }^{6}$ Azhar Arsyad, op.cit, hlm. 4-5

${ }^{7}$ Atwi Suparman, Desain instruksional, (Jakarta: PAC-PPAI Depdiknas, 2001), hlm. 187

8 Newby, op.cit, hlm. 17

${ }^{9}$ Kemp \& Dayton, op.cit, hlm. 3-4
} 


\section{Media Gambar Animasi dan Fungsinya dalam Pembelajaran}

Media gambar animasi/MGA menurut Merril, et.al.: "Animation, like motion picture, films and television, is an optical illution. We actually only see a series of still pictures in rapid succession. Small changes in position of certain objects in successif pictures of frames fool the human eye into perceiving motion. With televition, this illution of motion is achieved by displaying 30 frames every second, whereas film displays 24 frames per second. Adequate hypermedia animations may run from 12 to 16 frame per second".10

Maksudnya: animasi, seperti gambar gerak, televisi dan film-film, merupakan ilusi penglihatan. Sebetulnya kita hanya melihat serangkaian gambar mati berturut-turut dengan cepatnya. Perubahan kecil posisi objek tertentu pada frame gambar secara berturut-turut mengelabuhi mata manusia pada gerakan yang dilihat. Pada televisi, ilusi gerakan diperoleh dengan mempertunjukkan 30 frame setiap menit, tapi film mempertunjukkan 24 frame per menit. Animasi hypermedia cukup 12 sampai 16 frame per menit.

Animasi juga merupakan kumpulan gambar yang diolah sedemikian rupa sehingga menghasilkan gerakan animasi, mewujudkan ilusi (illusion) bagi pergerakan dengan memaparkan atau menampilkan satu urutan gambar yang berubah sedikit demi sedikit (progressively) pada kecepatan yang tinggi. Animasi digunakan untuk memberi gambaran pergerakan bagi sesuatu objek. Ia membolehkan sesuatu objek yang tetap atau statis dapat bergerak dan kelihatan seolah-olah hidup. Animasi multimedia merupakan proses pembentukan gerak dari berbagai media atau objek yang divariasikan dengan efek-efek dan filter, gerakan transisi, suara-suara yang selaras dengan gerakan animasi tersebut. ${ }^{11}$

Gambar animasi/GA yang sudah berbentuk film atau gambar hidup dan video merupakan gambar-gambar dalam frame dimana frame demi frame diproyeksikan melalui lensa proyektor secara mekanis sehingga pada layar terlihat gambar itu hidup. Film bergerak dengan cepat dan bergantian sehingga memberikan visual yang kontinyu. Film dan video dapat menggambarkan suatu objek yang bergerak bersama-sama dengan suara alamiah atau suara yang sesuai. Kemampuan film dan video melukiskan gambar hidup dan suara memberinya daya tarik tersendiri. Media ini umumnya bertujuan untuk hiburan, dokumentasi, dan pendidikan. Media tersebut dapat menyajikan informasi, memaparkan proses, menjelaskan konsep-konsep yang rumit, mengajarkan keterampilan, menyingkat atau memperpanjang waktu, dan mempengaruhi sikap. Film merupakan

\footnotetext{
10 Merril P. F., Computer in education. 3rd Ed. (Boston: Allin \& Bacon, A Simon \& Schuster Company Needham Heights, Mass, 1996), hlm. 185

11 http://www.uncur.ac.id/animasi-multimedia-pembelajaran/
} 
pengganti alam sekitar dan bahkan dapat menunjukkan objek yang secara normal tidak dapat dilihat, seperti cara kerja jantung ketika berdenyut. ${ }^{12}$

Gambar animasi/GA saat ini telah banyak diformat dalam sebuah CD/Compact Disc atau video interaktif. Video interaktif merupakan suatu sistem penyampaian pengajaran yang materi video rekamannya disajikan dengan kontrol komputer kepada siswa yang tidak hanya mendengar dan melihat video dan suara, tetapi juga memberikan respons yang aktif, dan respon itu yang menentukan kecepatan dan sekuensi penyajian. Peralatan yang diperlukan antara lain komputer, video disc lasser, dan layar monitor. CD merupakan sistem penyimpanan dan rekaman video dimana signal audio-visual direkam pada disket plastik, bukan pada pita magnetik. ${ }^{13}$

Gambar animasi/GA dalam sebuah aplikasi multimedia dapat menjanjikan suatu visual yang lebih dinamik serta menarik kepada penonton karena ia memungkinkan sesuatu yang mustahil atau kompleks dalam kehidupan nyata dapat direalisasikan di dalam aplikasi tersebut. Animasi digunakan untuk memberikan gambaran pergerakan bagi sesuatu objek. Ia menjadikan suatu objek yang tetap/ statis dapat bergerak dan kelihatan seolah-olah hidup. ${ }^{14}$

Animasi dapat berbentuk dua dimensi, tiga dimensi ataupun melalui berbagai kesan khas. Apapun bentuk animasi yang digunakan, ia mampu menghasilkan perbedaan dalam program yang mendukungnya karena sifat manusia menyukai sesuatu yang dinamik dan bukan statik. Walaupun demikian, proses penghasilan animasi bukanlah sesuatu yang mudah. Diperlukan pengalaman, kemahiran serta kepakaran yang tinggi bagi tujuan penghasilan. Pakar animasi yang sering dikenal sebagai animator diperlukan dalam jumlah yang banyak dalam menghasilkan suatu animasi yang berkualitas tinggi. Animasi komputer membutuhkan grafik komputer untuk menambahkan dimensi masa untuk menunjukkan pergerakan (motion).

Ada tiga jenis format animasi: pertama, animasi tanpa sistem kontrol, animasi ini hanya memberikan gambaran kejadian sebenarnya (behavioural realism), tanpa ada kontrol sistem. Misal untuk pause, memperlambat kecepatan pergantian frame, Zoom in, Zoom Out, bisa jadi animasi terlalu cepat, pengguna tidak memiliki waktu yang cukup untuk memperhatikan detail tertentu karena tidak ada fasilitas untuk pause dan zoom in. Kedua, animasi dengan sistem kontrol, animasi ini dilengkapi dengan tombol kontrol. Hal ini memungkinkan pengguna untuk menyesuaikan animasi dengan kapasitas pemrosesan informasi mereka. Namun kekurangannya, terletak pada pengetahuan awal

${ }^{12}$ Azhar Arsyad, op.cit, hlm. 49

${ }^{13} \mathrm{Ibid}$., hlm. 36

14 Tan Seng Chee, Teaching and Learning with Technology: an Asia Pasific Perspective, (Singapore: Prentice Hall, 2003), hlm. 139 
(prior knowledge) atas materi yang dipelajari menyebabkan murid tidak tahu mana bagian yang penting dan harus diperhatikan guna memahami materi dan yang tidak penting. Seringkali murid lebih memperhatikan bagian yang tampak lebih menonjol secara perseptual. Ketiga, animasi manipulasi langsung (Direct-Manipulation Animation (DMA)). DMA menyediakan fasilitas untuk pengguna berinteraksi langsung dengan kontrol navigasi (misal tombol dan slider). Pengguna bebas untuk menentukan arah perhatian dan kejadiannya dapat diulang. 15

Animasi banyak dimanfaatkan untuk kebutuhan dalam berbagai kegiatan, mulai kegiatan santai sampai serius, sebagai fungsi utama sampai fungsi tambahan atau hiasan. Pemanfaatan media pembelajaran terdapat dalam komponen metode mengajar sebagai salah satu upaya untuk mempertinggi proses interaksi guru-siswa dan interaksi siswa dengan lingkungan belajarnya. Fungsi utama penggunaan media gambar (termasuk gambar animasi) adalah: (a) fungsi edukatif; artinya mendidik dan memberikan pengaruh positif pada pendidikan. (b) fungsi sosial; memberikan informasi yang autentik dan pengalaman berbagai bidang kehidupan dan memberikan konsep yang sama kepada setiap orang. (c) fungsi ekonomis; memberikan produksi melalui pembinaan prestasi kerja secara maksimal, (d) fungsi politis; berpengaruh pada politik pembangunan, (e) fungsi seni budaya dan telekomunikasi, yang mendorong dan menimbulkan ciptaan baru, termasuk pola usaha penciptaan teknologi kemediaan yang modern. ${ }^{16}$

Fungsi praktis yang dijalankan oleh media gambar animasi adalah: (1) mengatasi perbedaan pengalaman pribadi peserta didik, misalnya VCD gambar animasi tentang kehidupan di perkotaan sangat diperlukan oleh anak yang tinggal di daerah pedesaan, (2) mengatasi batas ruang dan kelas, misalnya gambar animasi rumah, gedung perkantoran, sawah-ladang, dan sebagainya, (3) mengatasi keterbatasan kemampuan indera, (4) mengatasi peristiwa alam, misalnya animasi peristiwa letusan gunung berapi untuk menerangkan gejala alam, (5) menyederhanakan kompleksitas materi, dan (6) memungkinkan siswa mengadakan kontak langsung dengan masyarakat atau alam sekitar.

Media gambar animasi/MGA digunakan untuk menunjang keberhasilan pembelajaran terutama dalam memahami konsep-konsep yang abstrak. Media ini dapat memberikan makna bagi kata-kata, siswa dapat melihat invensi/hasil penemuan baru, tidak hanya mendengar dan membaca. Hal yang demikian dapat menambah minat, perhatian serta motivasi untuk belajar. Siswa juga dapat mengidentifikasi objek atau subjek, dapat menambah efektivitas dengan menambah wawasan informasi dengan memberikan highlight yang menyeluruh dan menambah ingatan, memperjelas yang nyata dan yang animasi/

15http://www.eduBenchmark.com/metodologi-pembelajaran/belajar-lebih-menyenangkan-dengan-

16 Oemar Hamalik. Media pendidikan, (Bandung: Citra Aditya Bakti, 1994), hlm. 12 
abstrak, mengilustrasikan prosedur, memberi contoh, mengidentifikasi bagian-bagian dan jenis-jenis, menggambarkan persamaan dan perbedaan berbagai objek dan menambah efisiensi dari penyajian. Media gambar ini juga bisa menarik perhatian, merangsang dan inkuiri, membantu mencapai tujuan yang mensyaratkan identifikasi orang, tempat, dan barang serta menimbulkan rasa ingin tahu dan memberikan informasi yang jelas untuk tes dan evaluasi. ${ }^{17}$

Animasi digunakan dalam media pembelajaran untuk dua alasan. Pertama, untuk menarik perhatian siswa dan memperkuat motivasi. Animasi ini biasanya berupa tulisan atau gambar yang bergerak-gerak, animasi yang lucu, aneh yang sekiranya akan menarik perhatian siswa. Animasi ini tidak ada hubungannya dengan materi yang akan diberikan kepada murid. Fungsi yang kedua adalah sebagai sarana untuk memberikan pemahaman kepada murid atas materi yang akan diberikan.

Animasi multimedia sebagai bagian dari TI (Teknologi Informasi) dapat mendukung dalam pembelajaran. Animasi multimedia memberikan kesan menyenangkan dan membantu proses pembelajaran, dan membantu anak mengingat bahan pelajaran karena terdapat ilustrasinya.

Dalam sebuah jurnal internasional disebutkan, bahwa gambar animasi memiliki beberapa fungsi, diantaranya adalah: fungsi memungkinkan (enabling function), fungsi memfasilitasi (fasilitating function), dan fungsi menghalangi (inhibiting function). Fungsi memungkinkan adalah jika media gambar animasi memberikan sejumlah proses kognitif kepada siswa lebih mudah dari gambar statis. Gambar animasi dapat memberikan informasi tambahan dan memungkinkan dapat memberikan proses kognitif lebih banyak dibandingkan gambar statis. Fungsi memfasilitasi adalah jika gambar animasi dapat membuat proses kognitif yang spesifik lebih mudah untuk dilakukan melalui dorongan eksternal. Gambar animasi dapat memberikan dorongan eksternal melalui simulasi mental. Dan fungsi menghalang jika gambar animasi justru menghalangi proses kognitif.18

Ada berbagai jenis animasi berdasarkan manfaatnya sebagai media yang digunakan untuk berbagai kebutuhan diantaranya: (1) Media hiburan, (2) Media presentasi, (3) Media iklan/promosi, (4) Media llmu pengetahuan, (5) Media bantu/tools, (6) Media pelengkap. ${ }^{19}$

Animasi yang dimanfaatkan untuk media ilmu pengetahuan memiliki kemampuan untuk dapat memaparkan sesuatu yang rumit atau komplek atau sulit untuk dijelaskan dengan hanya gambar atau kata-kata saja. Dengan kemampuan ini maka animasi dapat digunakan untuk menjelaskan suatu materi yang secara nyata tidak dapat terlihat oleh mata, dengan cara melakukan visualisasi maka materi yang dijelaskan dapat tergambar-

\footnotetext{
${ }^{17}$ Newby, op.cit., hlm. 103

$18 \mathrm{http} / / /$ www.internationaljournal.com/2007/enabling-facilitating-and-inhibiting-effects-in-learningfrom-animated-pictures/

${ }^{19} \mathrm{http} / / /$ www.uncur.acid/animasi-multimedia-pembelajaran/html
} 
kan. Selain itu animasi sebagai media ilmu pengetahuan dapat dijadikan sebagai perangkat ajar yang siap kapan saja untuk mengajarkan materi yang telah dianimasikan, terutama dengan adanya teknologi interaktif pada saat ini baik melalui perangkat komputer ataupun perangkat elektronik lainnya. Pada perangkat komputer media ini dikenal dengan istilah CAI atau Computer-Aided Intruction atau Computer-Assisted Intruction. Contohnya adalah animasi dokumenter Dinosourus, pembelajaran IPS, pembelajaran shalat dan cara baca Al-Qur'an, perjalanan dalam dunia maya, ensiklopedi jagat raya, darah dalam tubuh manusia, dan sebagainya.

Animasi multimedia digunakan dalam pembelajaran karena beberapa tujuan tertentu, yaitu: 1) Kualitas, seperti penguasaan materi, penggunaan perangkat lunak multimedia dalam proses belajar mengajar akan meningkatkan efisiensi, meningkatkan motivasi, memfasilitasi belajar aktif, memfasilitasi belajar eksperimental, konsisten dengan belajar berpusat pada siswa, dan memandu untuk belajar lebih baik. 2) Waktu yang singkat untuk mencapai tujuan tertentu dalam belajar. Animasi multimedia mampu mempercepat pemahaman sehingga belajar menjadi lebih singkat. 3. Efisiensi biaya, bahan pembelajaran lebih murah dalam bentuk digital yang disimpan dalam disk. Sebuah CD-ROM bisa menyimpan sekitar 680 MB data, setara dengan 250.000 halaman buku atau 200 buku atau 2 rak buku. Harga Compact Disc tidaklah mahal, sementara mampu menyimpan banyak data, maka CD-ROM menjadi salah satu media pilihan termurah untuk menerbitkan berbagai aplikasi multimedia di abad ke-21 yang bisa dimanfaatkan untuk membantu proses pembelajaran.

\section{Keunggulan dan Kelemahan MGA dalam Pembelajaran}

Animasi merupakan salah satu objek dari multimedia. Sedang multimedia merupakan penggunaan beberapa media yang berbeda untuk menggabungkan dan menyampaikan informasi dalam bentuk teks, audio, grafis, animasi, dan video.

Ada enam kriteria untuk menilai multimedia interaktif, yaitu:20 (1) kemudahan navigasi. (2) kandungan kognisi. (3) pengetahuan dan presentasi informasi. Apakah program telah memenuhi kebutuhan pembelajaran si pembelajar atau belum. (4) integrasi media, media harus mengintegrasikan bahan yang harus dipelajari. 5) estetik, menarik minat pembelajar (tampilan yang artistik). (6) fungsi secara keseluruhan. Program yang dikembangkan harus memberikan pembelajaran yang diinginkan oleh pembelajar. Pada waktu seorang selesai menjalankan program dia akan merasa telah belajar sesuatu.

MGA menjadi pilihan untuk menunjang proses belajar yang menyenangkan, menarik, memperkuat motivasi, dan menanamkan pemahaman pada siswa tentang materi yang

${ }^{20} \mathrm{http}: / /$ www.ialf.edu/membuat-media-pembelajaran-interaktif-dengan-piranti-lunak-presentasi/ 
diajarkan. Animasi memiliki keunggulan dibanding media lain seperti gambar statis atau teks. Keunggulan animasi adalah kemampuannya untuk menjelaskan suatu kejadian secara sistematis dalam tiap waktu perubahan. Ini sangat membantu dalam menjelaskan prosedur dan urutan kejadian. Meski disisi lain kemampuan memori otak manusia sangat bepengaruh dalam keefektifan penggunaan animasi. Selain kemampuan memori otak, pengetahuan awal (prior knowledge) mengenai konsep yang akan dijelaskan juga mempengaruhi tingkat keefektifan animasi. Bagi pemula yang tidak memiliki pengetahuan awal akan cenderung untuk lebih memperhatikan perubahan animasi yang menarik secara perseptual dibandingkan dengan perubahan yang penting dalam memahami materi. ${ }^{21}$

Media animasi yang siap pakai (by utilization), yang terformat dalam CD-ROM yang dipergunakan untuk pembelajaran, memiliki beberapa keunggulan antara lain:

Locating Selection. Students and teachers can quickly locate selections on CDs and can program machines to play any desired sequence. Information can be selectively retrieved by students or programmed by the teacher. Resistence to Damage. There are no grooves to scratch or tape to tangle and break. Stains can be washed off and ordinary scratches do not affect playback.22

Media yang berbentuk film dan video memiliki keunggulan-keunggulan, antara lain: (1) Dapat melengkapi pengalaman-pengalaman dasar dari siswa ketika mereka membaca, berdiskusi, berpraktik, dan lain-lain. (2) Dapat menggambarkan suatu proses secara tepat yang dapat disaksikan secara berulang-ulang jika dipandang perlu. (3) Mendorong dan meningkatkan motivasi, menanamkan sikap dan segi-segi afektif lainnya, mengandung nilai-nilai yang dapat mengandung pemikiran dan pembahasan dalam kelompok siswa dan bahkan dapat membawa dunia ke dalam kelas. (4) Dapat menyajikan peristiwa yang berbahaya apabila dilihat secara langsung. (5) Dapat ditunjukkan kepada kelompok kecil, kelompok yang heterogen dan individu. (6) Dapat mempercepat atau memperlambat suatu peristiwa atau kejadian. ${ }^{23}$

Kelemahan dari media gambar animasi yang terformat dalam CD-ROM adalah "Cost. The cost of CD players has limited their acceptance in the education market. limited recording capability. Student and teacher cannot produce their own CDs as cheaply and easily as they can cassettes."24

Selain itu, kelemahan gambar animasi dalam bentuk film dan video adalah: (1) memerlukan waktu yang banyak dan biaya yang mahal dalam pengadaan, (2) saat film diputar, gambar-gambar bergerak terus sehingga tidak semua siswa dapat mengikuti

\footnotetext{
${ }^{21}$ http://www.pribtk.blog2.plaza.com/efektifitas-multimedia/html

22 Newby, op.cit, hlm. 111

${ }^{23}$ Azhar, op.cit, hlm. 49-50

${ }^{24}$ Newby, op.cit. hlm. 111
} 
informasi yang ingin disampaikan, kecuali yang diformat dengan sistem kontrol atau manipulasi/DMA, (3) film atau video yang tersedia tidak selalu sesuai dengan kebutuhan dan tujuan belajar kecuali yang dirancang dan diproduksi khusus untuk kebutuhan sendiri. ${ }^{25}$ Satu poin lagi dari kelemahan media audiovisual ini, yaitu apa yang telah lewat sulit untuk diulang kecuali diputar kembali atau dengan sistem kontrol atau manipulasi diulang setiap poin yang akan menjadi tekanan. ${ }^{26}$

Dalam teori animasi mental dinyatakan bahwa, murid yang diperlihatkan frameframe dalam animasi tetap perlu menganimasikan secara mental bagaimana sistem bekerjanya. Animasi mental tersebut mengarah kepada pemahaman dan pemrosesan informasi yang lebih baik. DMA (Direct-Manipulation Animation) memungkinkan pengguna untuk berinteraksi langsung secara aktif dengan animasi, oleh karena itu akan memberikan dukungan kepada murid untuk membangun model mental dinamis atas proses yang terjadi. Pembelajaran menggunakan multimedia, memerlukan pembelajaran aktif murid atas materi instruksional. Hanya dengan memperlihatkan animasi saja mungkin tidak memberikan bantuan berarti bagi murid untuk belajar. Terlebih, aspek dinamis dari berbagai elemen dalam animasi yang terkontrol akan membutuhkan lebih banyak pemrosesan kognisi saat mereka berusaha untuk mempersepsi dan mengkomprehensi isi animasi. ${ }^{27}$

Rahadi mengatakan, media gambar yang baik, termasuk di dalamnya animasi, harus memiliki karakteristik sebagai berikut: (1) autentik, (2) sederhana, (3) ukuran proporsional, (4) memadukan antara keindahan dengan kesesuaiannya untuk mencapai tujuan pembelajaran, (5) mengandung message.28 Tidak setiap gambar animasi yang bagus merupakan media yang baik. Sebagai media yang baik, gambar animasi hendaklah bagus dari sudut seni dan sesuai dengan tujuan pembelajaran yang ingin dicapai.

\section{E. Pembelajaran IPS di Sekolah Dasar}

Belajar merupakan suatu proses perubahan tingkah laku yang relatif tetap pada diri seseorang sebagai akibat interaksi dengan lingkungan. Jadi perubahan ini bukan karena kematangan, evolusi, efek motivasi, dan perubahan stimulasi. Domjan mengatakan: "Learning is a relatively enduring change in the potential to engage in a particular behavior

\footnotetext{
${ }^{25}$ Azhar Arsyad, op.cit. hlm. 50

${ }^{26}$ Basyiruddin Usman \& Asnawir. Media pembelajaran, (Jakarta: Ciputat Pers, 2002), hlm. 96 animasi/

${ }^{27} \mathrm{http}: / /$ www.eduBenchmark.com/metodologi-pembelajaran/belajar-lebih-menyenangkan-dengan-

28http://www.curriki.org/media-pembelajaran/
} 
resulting from experience with environmental events specifically related to that behavior". ${ }^{29}$ Senada dengan pengertian di atas adalah: "Learning is a persisting change in human performance or performance potential \{brought\} about as result of the learner's interaction with the environment" "Learning occurs when experience causes a relatively permanent change in an individual's knowledge or behavior".30 Maksudnya: "bahwa belajar adalah perubahan yang tetap pada perilaku manusia atau perilaku potensial sebagai hasil interaksi pelajar dengan lingkungan" dan "belajar terjadi manakala pengalaman menyebabkan perubahan yang relatif tetap pada pengetahuan dan perilaku individu".

Proses belajar bisa dalam bentuk apa pun, di mana pun, dan kapan pun saat individu berinteraksi dengan lingkungannya dan memperoleh hal-hal yang baru. Hal-hal tersebut dapat berupa pengalaman, pengetahuan, nilai-nilai/sikap, keterampilan dan lain sebagainya yang memungkinkan seseorang bisa menjadi semakin dewasa. Kegiatan belajar merupakan kegiatan yang sistematis yang direncanakan dengan baik, dapat berlangsung melalui sumber langsung maupun sumber tidak langsung atau sumber lain yang berupa pesan/materi, orang/pakar keilmuan, bahan/software, alat/hardware, teknik/metode, dan lingkungan (by design dan by utilization).

Untuk melaksanakan kegiatan pembelajaran IPS dapat dilakukak dengan berbagai pendekatan. Diantaranya dengan menggunakan pendekatan terpadu. Penggunaan pendekatan terpadu, bisa digunakan berbagai strategi, diantaranya adalah strategi pembelajaran CTL (Contextual Teaching and Learning). Yakni, suatu konsep belajar yang membantu guru mengaitkan antara materi yang diajarkannya dengan situasi-situasi dunia nyata siswa dan mendorong siswa membuat hubungan antara pengetahuan yang dimilikinya dengan penerapannya dalam kehidupan mereka sehari-hari, memadukan dunia anak didik dengan dunia di luar anak didik, dengan melibatkan tujuh komponen utama pembelajaran efektif, yakni: konstruktivisme (constructivism), bertanya (questioning), menemukan (inquiry), masyarakat belajar (learning community), pemodelan (modeling), dan penilaian sebenarnya (authentic assessment).

Beberapa strategi pembelajaran yang dapat dikembangkan oleh guru melalui pembelajaran kontekstual, antara lain: (1) Pembelajaran berbasis masalah, (2) Memanfaatkan lingkungan siswa untuk memperoleh pengalaman belajar, (3) Memberikan aktivitas kelompok, (4) Membuat aktivitas belajar mandiri, (5) Membuat aktivitas belajar bekerjasama dengan masyarakat, (6) Menerapkan penilaian autentik.

Pendekatan proyek untuk pembelajaran IPS di Sekolah Dasar juga dianggap sebagai cara efektif untuk model pembelajaran terpadu:

${ }^{29}$ Domjan, M., The essentials of conditioning and learning, (Mexico: Thomson Wadsworth, 2005), hlm. 7

${ }^{30}$ Newby, op.cit, hlm. 8 
The project approach to social studies is an effective way to create an interdisciplinary learning model. Projects have a real-world flavor to them, and that makes them appealing to children. They also have a beginning and end point, which allows students and teachers a better sense of what they are accomplishing. ${ }^{31}$

Pendekatan proyek dalam kajian sosial merupakan cara yang efektif untuk membuat model pembelajaran terpadu/interdisiplin. Dengan pendekatan ini terasa sebagai dunia nyata bagi anak didik, dan anak juga dekat dengan dunia nyata. Model proyek juga memiliki titik awal dan akhir, yang mengarahkan siswa-guru untuk memiliki rasa saling melengkapi. Jenis-jenis proyek interdisiplin yang dapat dilakukan untuk menjadi wahana pembelajaran bagi siswa meliputi empat hal yaitu proyek pelayanan, proyek pelayanan produksi, proyek produksi, proyek pemecahan masalah dan proyek lingkup sekolah. Proyek-proyek siswa itu menjadi wahana pembelajaran. "Kinds of interdisciplinary projects ...four distinctly different kinds of projects will be discussed here: service projects, product service projects, production projects, problem solving projects, and schoolwide projects".32

Namun, guru baru lebih menyukai strategi pembelajaran expository. Karena situasi mengajar cukup dapat dikontrol, dapat mengurangi pengelolaan perhatian sampai minimal, tujuan dapat dibuat secara khusus, dan materi pelajaran anak-anak dapat dipersiapkan sejak awal. ${ }^{33}$ Ellis menyatakan ada 4 jenis tema yang dapat diterapkan dalam strategi pembelajaran IPS: (1) sebab-akibat (cause and effect), (2) persamaan dan perbedaan (commonality and diversity), (3) pola-pola dan sistem (systems and patterns), (4) perputaran dan perubahan (cycles and change). ${ }^{34}$

Pendekatan tematik juga merupakan salah satu pendekatan yang dapat digunakan dalam pembelajaran IPS di SD, sebagaimana telah diterapkan dalam kurikulum pembelajaran IPS di SD, terutama pada kelas I-III SD/MI/SDLB. Pendekatan tematik sangat cocok untuk otak karena otak merupakan sebuah detector pola yang dapat mempersepsi hubungan interaktif. Pengajaran yang memfokuskan pada tema-tema sebagai pengaturan makna-makna adalah pengajaran tematik. Diharapkan pembelajaran terpadu dengan tema-tema global yang kontekstual, maka otak dirangsang untuk menghubungkan suatu hal dan untuk "mencipta".

Bentuk pembelajaran IPS dengan model pembelajaran terpadu mengandung dua hal yang harus dipenuhi sebagai prasyarat ideal, yaitu: (1) suatu metode pembelajaran yang

\footnotetext{
31Ellis, Arthur K, Teaching and Learning Elementary Social Studies, Fifth Edition, (Prentice Hall/Allyn \& Bacon, 1995), hlm. 315

32 Ibid., hlm. 300

33 Jarolimek, J., Social Studies in Elementary Education, (New York: Mac Millan Publishing Company, 1986), hlm. 20

${ }^{34}$ Ellis, Arthur K, op.cit., hlm. 300
} 
memadukan materi belajar dari berbagai disiplin ilmu baik secara multidisiplin/ interdisplin; multidisiplin atau lintas bidang misalnya IPS dengan IPA, Matematika, dan bahasa; interdisplin atau dalam bidang yang sama dalam pengetahuan sosial, misalnya mengajarkan ekonomi sekaligus memuat materi sejarah, geografi, atau aspek sosiologi. (2) keterpaduan dalam upaya mengakses pengetahuan (dengan membaca, menulis, diskusi, role play, presentasi praktik unjuk kerja, maupun mencermati CD pembelajaran interaktif dalam mencapai keterampilan tertentu).

Anak sekolah dasar memiliki karakteristik perkembangan tertentu. Dilihat dari sisi perkembangan fisiknya sudah mulai mencapai kematangan. Dari sistem-sistem rangka, anak-anak tumbuh kira-kira 2-3 inci pertahun. Massa dan kekuatan otot secara berangsurangsur bertambah. Kaki semakin panjang dan tubuh semakin langsing ketika "gemuk bayi" berkurang. Pertumbuhan pelan dan tetap. Jadi, mereka telah mampu mengontrol tubuh dan keseimbangannya. Pada keterampilan motoriknya, perkembangan motorik anak-anak menjadi lebih halus dan terkoordinasi. Anak mendapat kendali/control yang lebih besar atas tubuhnya dan dapat duduk serta dapat mengikuti pembicaraan beberapa saat. Tapi hidup mereka harus berorientasi kegiatan dan sangat aktif. Meningkatnya myelin sistem syaraf pusat tercermin dalam membaiknya keterampilan-keterampilan motorik halus. Meningkatnya keterampilan motorik halus tercermin di dalam keterampilan-keterampilan menulis tangan. Anak laki-laki biasanya lebih baik pada keterampilan-keterampilan motorik kasar dan anak perempuan pada keterampilan-keterampilan motorik halus. ${ }^{35}$

Anak-anak pada masa pertengahan dan akhir ini harus lebih banyak diberikan aktivitas-aktivitas untuk melatih otot-ototnya seperti latihan-latihan dan olahraga. Anak yang berada di kelas awal SD berada pada rentangan usia dini. Masa usia dini merupakan masa yang pendek tetapi merupakan masa yang sangat penting bagi kehidupan seseorang. Oleh karena itu, pada masa ini seluruh potensi yang dimiliki anak perlu didorong sehingga akan berkembang secara optimal.

Pada perkembangan kognitifnya, anak usia SD berada pada fase operasional konkret/concret operational. Pemikiran anak pada tahap ini terdiri dari operasi-operasi/ tindakan-tindakan mental yang memungkinkan anak melakukan secara mental apa yang telah dilakukan sebelumnya secara fisik. Anak-anak juga dapat melakukan operasi/ tindakan secara mental; memperlihatkan keterampilan-keterampilan konservasi. Anakanak juga bernalar secara logis menggantikan penalaran intuitif tetapi hanya di dalam keadaan-keadaan konkret. Anak pada fase operasional konkret tak dapat membayangkan atau berfikir tentang sesuatu yang abstrak misalnya membayangkan langkah-langkah persamaan aljabar. Selain itu, ciri-ciri tahapan pemikiran operasional konkret adalah

35 Santrock, op.cit. hlm. 310 
memiliki keterampilan klasifikasi, yakni dapat menggolongkan benda-benda ke dalam perangkat-perangkat dan sub-sub perangkat dan benalar tentang keterkaitannya.

Pada rentang usia tersebut anak mulai menunjukkan perilaku belajar sebagai berikut: (1) mulai memandang dunia secara objektif, bergeser dari satu aspek situasi ke aspek lain secara reflektif dan memandang unsur-unsur secara serentak, (2) mulai berpikir secara operasional, (3) mempergunakan cara berpikir operasional untuk mengklasifikasikan benda-benda, (4) membentuk dan mempergunakan keterhubungan aturan-aturan, prinsip ilmiah sederhana, dan mempergunakan hubungan sebab-akibat, dan (5) memahami konsep substansi, volume zat cair, panjang, lebar, luas, dan berat.

Memperhatikan tahapan perkembangan berpikir tersebut, kecenderungan belajar anak usia sekolah dasar memiliki tiga ciri, yaitu: concrete; Konkret mengandung makna proses belajar beranjak dari hal-hal yang kongkret yakni yang dapat dilihat, didengar, dibaui, diraba, dan diotak-atik, dengan penekanan pada pemanfaatan lingkungan sebagai sumber belajar. Pemanfaatan lingkungan akan menghasilkan proses dan hasil belajar yang lebih bermakna dan bernilai, sebab siswa dihadapkan dengan peristiwa dan keadaan yang sebenamya, keadaan yang alami, sehingga lebih nyata, lebih faktual, lebih bermakna, dan kebenarannya lebih dapat dipertanggungjawabkan.

Integrative; pada tahap usia sekolah dasar anak memandang sesuatu yang dipelajari sebagai suatu keutuhan, mereka belum mampu memilah-milah konsep dari berbagai disiplin ilmu, hal ini melukiskan cara berpikir anak yang deduktif yakni dari hal umum ke bagian demi bagian. Hierarchies; pada tahapan usia sekolah dasar, cara anak belajar berkembang secara bertahap mulai dari hal-hal yang sederhana ke hal-hal yang lebih kompleks. Sehubungan dengan hal tersebut, maka perlu diperhatikan mengenai urutan logis, keterkaitan antar materi, dan cakupan keluasan serta kedalaman materi.

\section{F. MGA untuk Pembelajaran IPS di Sekolah Dasar}

Media adalah salah satu unsur penting dalam pembelajaran yang dapat membantu dalam mencapai tujuan pembelajaran seperti yang diharapkan. Media pembelajaran merupakan komponen sumber belajar atau wahana fisik yang mengandung materi instruksional di lingkungan siswa yang dapat merangsang siswa untuk belajar. Berbagai media memiliki kemampuan-kemampuan yang berbeda yang kadangkala tidak dimiliki oleh guru. Misalnya adalah kemampuan fiksatif yakni kemampuan media dalam merekam, menyimpan, melestarikan, dan merekonstruksi suatu peristiwa atau objek. Kemampuan manipulatif, yakni kemampuan media untuk memanipulasi segala hal, mempercepat atau memperlambat suatu proses, merekam gambar hidup, dan sebagainya. Dan kemampuan distributif, yakni kemampuan mendistribusikan/mentransportasikan suatu objek melalui ruang dan secara bersamaan kejadian tersebut disajika kepada 
sejumlah siswa dengan stimulus pengalaman yang relatif sama mengenai kejadia tersebut. $^{36}$

Azhar Arsyad juga menyebutkan, terdapat berbagai pilihan media untuk pembelajaran (termasuk untuk pembelajaran IPS) mulai dari media tradisional sampai media teknologi mutakhir, mulai dari yang dirancang sendiri (by design) atau yang tinggal pakai (by utilization). Diantara media tradisional adalah: (1) visual diam yang diproyeksikan: proyeksi opaque/tak tembus pandang, proyeksi overhead, slide, filmstrip. (2) visual yang tak diproyeksikan: gambar, poster, foto, charts, grafik, diagram, pameran, papan info, papan bulu. (3) audio: rekaman piringan, pita kaset, cartridge. (4) penyajian multimedia: slide plus suara (tape), multi-image, visual dinamis yang diproyeksikan: film, tevisi, video. (5) cetak: buku teks, modul, teks terprogram, workbook, majalah ilmiah, berkala, lembaran lepas (hand-out). 6)permainan: teka-teki, simulasi, permainan papan. (6) relia: model, specimen (contoh), manipulatif (peta, boneka). ${ }^{37}$

Sedangkan media teknologi mutakhir adalah: (1) media berbasis telekomunikasi: telekonferen, kuliah jarak jauh. (2) Media berbasis mikroprosesor: Computer-Assisted Instruction/CAI, permainan komputer, sistem tutor intelijen, interactive video, hypertext, hypermedia, compact (video) disc.

Kemp \& Dayton membandingkan penggunaan media pembelajaran yang konvensional dan multimedia, ${ }^{38}$ dapat dilihat pada tabel berikut. Azhar Arsyad juga mengklasifikasikan media menjadi 5 jenis, yakni: media berbasis manusia seperti guru, instruktur, tutor, main peran, kegiatan kelompok, field trip; media berbasis cetak seperti buku, penuntun, buku latihan/workbook, alat bantu kerja, dan lembaran lepas; media berbasis visual seperti buku, alat bantu kerja, bagan, grafik, peta, gambar, transparansi, slide; media berbasis audiovisual seperti video, film, program slide-tape, televisi; dan media berbasis komputer seperti pengajaran dengan bantuan komputer, interactive video, hypertext. ${ }^{39}$

Perbandingan antara metode konvensional dan yang berbasis multimedia, dapat dilihat pada pemaparan tabel berikut:

\footnotetext{
${ }^{36}$ Azhar Arsyad, op.cit, hlm. 12-14

${ }^{37} \mathrm{Ibid}$, hlm. 33-35

${ }^{38}$ Kemp \& Dayton, op.cit., hlm. 281

${ }^{39}$ Azhar Arsyad, op.cit., hlm. 36
} 


\begin{tabular}{|l|l|l|}
\hline \multicolumn{2}{|c|}{ COMPARISONS OF MEDIA FOR CONVENTIONAL USE WITH } \\
MULTIMEDIA USES
\end{tabular}

Maksudnya kurang lebih adalah:

\section{PERBANDINGAN PENGGUNAAN MEDIA KONVENSIONAL DAN PENGGUNAAN MULTIMEDIA}

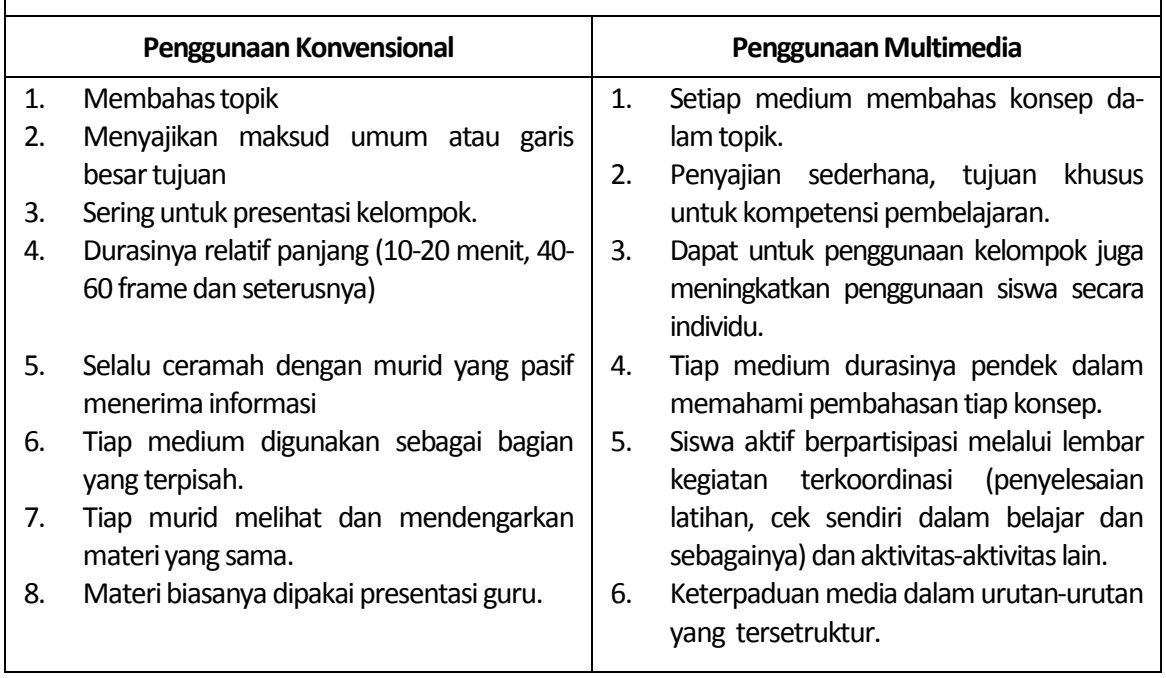


7. Variasi materi dapat diperoleh siswa sehingga siswa dapat memilih bahan sendiri

8. Siswa mempelajari bahan di tempatnya sendiri dan percaya diri.

Media yang digunakan dalam kegiatan pembelajaran IPS harus memuat materi/ bahan yang dapat diambil dari berbagai sumber. Pembuatan media pembelajaran untuk IPS, yang ideal harus melibatkan fakta yang kontekstual dengan dunia peserta didik, kebutuhan dalam pembelajaran dan tetap memiliki nilai-nilai universal.

Pemakaian media visual yang menggabungkan penggunaan audio untuk pembelajaran IPS memerlukan pekerjaan tersendiri untuk memproduksinya. Salah satu pekerjaan penting yang diperlukan adalah penulisan naskah dan storyboard yang memerlukan persiapan yang tidak sedikit, design, dan research. Naskah yang menjadi bahan narasi disaring dari pelajaran yang kemudian disintesis ke dalam apa yang ingin ditampilkan dan disampaikan. Narasi ini merupakan panduan bagi tim produksi untuk memikirkan bagaimana video memvisualisasikan materi pelajaran IPS. Pada awal pelajaran media harus mempertunjukkan sesuatu yang dapat menarik perhatian siswa. Misalnya animasi-animasi lucu. selanjutnya diikuti jalinan logis keseluruhan program yang dapat membangun rasa continuitas dan kemudian menuntun kepada kesimpulan atau rangkuman. Sambung-menyambungnya program dapat dikembangkan melalui penggunaan cerita atau problem yang memerlukan cerita. ${ }^{40}$

Ada beberapa cara praktis untuk menulis naskah narasi:

1. tulis singkat, padat, dan sederhana.

2. tulis seperti menulis judul berita.

3. tulis frase yang penting untuk melengkapi visualisasi.

4. hindari istilah teknis.

5. tulis dalam kalimat aktif.

6. setiap kalimat tidak lebih dari 15 kata.

7. setelah menulis narasi, baca dengan keras.

8. edit dan revisi naskah narasi.

Sedangkan dalam mengembangkan storyboard harus memperhatikan hal-hal berikut:

1. menetapkan jenis visual, misalnya gambar animasi, kartun, dan sebagainya.

2. pikirkan bagian program yang akan diberikan audio.

${ }^{40}$ Azhar Arsyad, op.cit., hlm. 94 
3. yakinkan seluruh isi pelajaran sudah tercakup dalam storyboard.

4. review storyboard sambil mengecek: semua visual dan grafik cocok dengan teks, pendahuluan menampilkan penarik perhatian, informasi penting telah tercakup, urutan interaktif telah digabungkan, strategi belajar telah digabungkan, narasi singkat padat, program mendukung latihan-latihan, alur dan organisasi program mudah diikuti dan dimengerti.

5. kumpulkan dan paparkan semua storyboard sehingga dapat terlihat semua.

6. minta anggota tim produksi untuk mereview dan mengkritik.

7. catat komentar, kritik, dan saran.

8. revisi untuk persiapan akhir sebelum mulai produksi.

Untuk media gambar visual yang tinggal pakai (by utilization) seperti film dan CD, guru IPS tidak membuat atau merancang sendiri. Selain membutuhkan waktu yang lama, juga dibutuhkan keahlian khusus. Guru bisa mencari/membeli film, video, atau CD yang ada di pasaran yang sesuai dengan mapel, SK, KD, indikator, isi, tujuan pembelajaran, dan harga yang terjangkau bagi lembaga pendidikan.

Dalam pembelajaran IPS di kelas guru memiliki tiga peranan utama yaitu: sebagai presenter, fasilitator, dan desainer. ${ }^{41}$ Agar pembelajaran IPS yang dilakukan oleh guru berhasil dengan bantuan media gambar animasi, maka langkah yang harus dilakukan oleh guru adalah: sebagai presenter, harus menyampaikan materi IPS dengan bantuan media gambar animasi secara menarik, menginformasikan tujuan pembelajaran, mengulangulang bahan sebelumnya, menyampaikan materi pada pertemuan sekarang, memberikan petunjuk yang jelas, memberikan performance, memberikan feedback, menilai perilaku, memberi retensi dan transfer.

Kedua, sebagai fasilitator harus menyiapkan media gambar animasi yang dapat mensupport belajar IPS siswa, menjadi sumber belajar siswa, dapat menjadi media komunikasi bagi pertukaran pandangan yang berbeda-beda, dapat bertindak sebagai alat kognitif untuk membantu siswa dalam menganalisis, mengkonstruksi, dan merepresentasikan pengetahuan. Dan ketiga, sebagai desainer, guru mendesain mapel IPS yang menggunakan media gambar animasi yang difokuskan pada belajar yang berpusat pada siswa.

Peran utama pembelajaran dengan menggunakan bantuan MGA adalah memfasilitasi belajar siswa dengan cara memberikan stimulus-lingkungan. Guru hendaknya dapat menentukan dan memilih media yang baik, yaitu: Pertama, gambar yang dipilih cukup memadai, pantas untuk tujuan pengajaran IPS yang dapat menampilkan gagasan, bagian, informasi atau konsep IPS secara jelas yang mendukung tujuan serta kebutuhan

41 Tan Seng Chee, Ed., op.cit. 2003: 3-5. Dan Frye, H. R., Techniques for Producing Visual Instructional Media, $2^{\text {nd }}$ ed., (New York: McGraw-hill Book Company, 1962), hlm. 36-40 
pengajaran. Gambar hendaknya realistik dan hidup, pewarnaan bagus, dan cukup besar sehingga rinciannya bisa diamati/dipelajari. Memilih MGA perlu memperhitungkan kesesuaiannya dengan tingkat usia anak, sederhana, gagasannya tidak kompleks, sesuai tingkat kecerdasan, lingkungan, pengalaman sebelumnya dan daya imajinasi. Kedua, gambar harus memenuhi persyaratan artistik yang bermutu, komposisinya baik, pewarnaan efektif, teknik penggambaran unggul bernilai lebih dari komposisi dan pewarnaan. Ketiga, gambar untuk tujuan pengajaran IPS harus cukup besar dan jelas. Keempat, validitas gambar, yaitu apakah gambar itu benar atau tidak, gambar-gambar melukiskan suasana dramatis atau mencekam, adegan yang ideal. Kelima, memikat perhatian anak-anak (hal-hal yang diminatinya).

Pembelajaran IPS haruslah optimal. Siswa harus mengalami pembelajaran yang bermakna, yang disertai dengan pencapaian tingkatan pemahaman yang lebih tinggi dari tingkatan pemahaman mereka sebelumnya. Ada 2 Faktor yang mempengaruhi keberhasilan siswa dalam pembelajaran IPS yaitu faktor internal dan faktor eksternal. Faktor internal: intelegensi, bakat, minat, kemampuan belajar, usia siswa/tingkat sekolah, motivasi, dan lain-lain. Dan faktor eksternal, yaitu lingkungan, cara belajar, keadaan ekonomi, keluarga, sosial, budaya, latihan dan penguatan, pendekatan, strategi, metode dan media pembelajaran yang digunakan guru dalam pembelajaran, dan sebagainya. ${ }^{42}$

Guru atau pendidik hendaknya memiliki kemampuan dalam menggunakan media yang berteknologi modern. Paturan Menteri Pendidikan Nasional No. 16 Tahun 2007 tentang Standar Kualifikasi Akademik dan Kompetensi Guru SD/MI sebagai tindak lanjut dari UU Guru dan Dosen pasal 32 mensyaratkan guru harus memiliki kompetensi di antaranya:

1) memanfaatkan teknologi informasi dan komunikasi untuk kepentingan pembelajaran (Butir kelima pada kompetensi pedagogik),

2) memanfaatkan teknologi informasi dan komunikasi untuk komunikasi dan pengembangan diri (Butir ke-24 pada kompetensi profesional).

Konsep awal dari penggunaan media dalam pembelajaran adalah dari pemikiran Johan Amos Comenius, bahwa "Tak ada sesuatu dalam akal pikiran manusia, tanpa terlebih dahulu melalui pengindraan". Berdasarkan pemikiran itu kemudian Comenius menulis buku bergambar, yang berjudul Orbis Sensualium Pictus (dunia tergambar), yang terbit tahun 1657.43 Perkembangan selanjutnya, para ahli dalam dunia pendidikan meneliti pengaruh penggunaan media dalam pembelajaran tersebut. Berdasarkan hasil penelitian dari lembaga riset dan penerbitan komputer terbukti bahwa seseorang hanya dapat mengingat apa yang dilihat sebesar 20\%, apa yang didengar 30\%, apa yang dia

${ }^{42}$ Azhar Arsyad, op.cit, hlm. 15

${ }^{43} \mathrm{http}: / /$ www.curriki.org/media-pembelajaran/html 
dengar dan lihat 50\%, dan 80\% dari apa yang dia dengar, lihat, dan kerjakan secara simultan. ${ }^{44}$ Artinya, hasil belajar yang diperoleh siswa sangat sedikit jika siswa hanya melihat atau mendengarkan guru berceramah.

Terkait dengan hal tersebut, Edgar Dale membuat klasifikasi pengalaman menurut tingkatan dari yang paling kongkret sampai kepada yang paling abstrak. Semakin kongkret proses pembelajaran yang dilakukan, maka akan semakin besar pengalaman belajar yang diperoleh siswa. Namun, semakin abstrak proses pembelajaran yang dilakukan, maka akan semakin kecil pengalaman belajar yang diperoleh siswa. Klasifikasi tersebut kemudian dikenal dengan nama kerucut pengalaman (cone of experience) Edgar Dale. $^{45}$

Menindaklanjuti fakta-fakta tersebut, dalam perkembangan terakhir ini telah banyak dikembangkan media-media pembelajaran baik yang bersifat tradisional maupun yang modern. Di antara media pembelajaran yang bersifat modern terdapat media yang berbasis multimedia. Multimedia pembelajaran seperti CAI (pembelajaran berbantuan komputer), CBI (pembelajaran berbasis komputer) mampu menampilkan teks, suara/ narasi, musik latar, gambar, animasi, gambar bergerak, video, dalam satu tampilan media, dan memungkinkan siswa dapat melakukan proses belajar mandiri. Media gambar animasi merupakan media yang penyajiannya diperlukan alat bantu lain seperti komputer, LCD, dan sebagainya. Media gambar animasi saat ini merupakan salah-satu media pembelajaran yang sudah dikenal oleh masyarakat dan sudah digunakan oleh beberapa sekolah di dalam kegiatan pembelajaran untuk membantu guru dalam melakukan peoses pembelajaran dengan optimal dan diharapkan hasilnya maksimal. Karena ketersediaan dan bantuan media dalam proses pembelajaran sangat berpengaruh dalam pencapaian pembelajaran siswa itu sendiri.

Media gambar animasi yang berupa film atau video merupakan media yang digunakan untuk mengkomunikasikan pesan pada siswa pada pembelajaran IPS meliputi bentuk-bentuk atau unsur-unsur verbal (teks atau kata-kata), sound/suara, juga unsurunsur grafik (gambar dan yang sejenis gambar) seperti drawing/lukisan, chart, gambar/ foto warna dan sejenisnya, poster dan kartun, dimana sumber-sumber media tersebut bisa berasal dari textbook, bahan-bahan referensi, koran, jurnal, baik yang dibuat sendiri oleh guru, ahli media maupun siswa. ${ }^{46}$

Media gambar animasi termasuk media yang masih jarang dipakai dalam pembelajaran IPS. Hal ini dikarenakan guru belum terbiasa menggunakan dan mengilustrasikan materi dengan gambar, padahal jika gambar animasi dibuat dan disajikan

\footnotetext{
${ }^{44} \mathrm{http}: / /$ www.curriki.org/media-pembelajaran/html

${ }^{45}$ Heinich, et al, Instructional media and the new technologies of learning, (New Jersey: Prentice-Hall, Inc., 1996), hlm. 16

${ }^{46}$ Newby, op.cit., hlm. 10
} 
sesuai dengan persyaratan yang baik, tentu akan menambah semangat dan motivasi siswa dalam mengikuti proses pembelajaran. Media gambar animasi, dapat memberi gagasan dan dorongan kepada guru dalam mengajar anak-anak Sekolah Dasar atau Madrasah Ibtidaiyah agar lebih kreatif dalam mengembangkan alat peraga agar para murid menjadi senang belajar.

Namun demikian, hendaknya penggunaan MGA dalam pembelajaran IPS tidak hanya digunakan untuk alasan hiasan atau hiburan semata. Sebaiknya berhati-hati dalam menggunakan MGA karena tidak semua animasi dapat digunakan dan efektif untuk pembelajaran dan tidak semua animasi itu menarik. ${ }^{47}$

Mengingat siswa Sekolah Dasar kelas IV (kurang lebih berusia 8/9 tahun) menurut Piaget masih berada dalam taraf berfikir operasional kongkret (antara usia 7-11), ${ }^{48}$ maka dalam pembelajaran IPS sedapat mungkin mengenalkan benda yang nyata yaitu melalui bantuan media yang dapat menimbulkan minat belajar dan meningkatkan motivasi belajar. Hal tersebut untuk mengatasi kejenuhan dalam belajar dan meningkatkan motivasi belajar yang akhirnya dapat membantu meningkatkan prestasi/hasil belajar siswa.

Dengan demikian media gambar animasi merupakan salah satu media pembelajaran yang efektif untuk mencapai hasil belajar yang baik kerena mengkombinasikan fakta dan gagasan secara jelas, kuat dan terpadu melalui pengungkapan kata-kata, gambar, dan gerak. Tapi guru juga perlu memahami prinsip-prinsip pendidikan untuk membantu anak mengerti akan hasil belajar, memiliki bahan, menciptakan kondisi belajar, menyiapkan lingkungan belajar, dan mendesain yang sesuai dan mengembangkan aktivitas yang mengarahkan pada pemikiran yang lebih tinggi.[]

47 Tan Seng Chee, op.cit., hlm. 139

${ }^{48}$ Santrock, op.cit. hlm. 42 


\section{DAFTAR PUSTAKA}

Atwi Suparman, Desain instruksional, Jakarta: PAC-PPAI Depdiknas, 2001.

Azhar Arsyad, Media pengajaran, Jakarta: Raja Grasindo Persada, 2004.

Basyiruddin Usman \& Asnawir, Media Pembelajaran, Jakarta: Ciputat Pers, 2002.

Depdiknas, Model Pembelajaran Terpadu IPS, Jakarta: Badan Penelitian dan Pengembangan Pendidikan Nasional, Pusat Kurikulum, t.th.

Domjan, M., The Essentials of Conditioning and Learning, Mexico: Thomson Wadsworth, 2005.

Ely, D.P. \& Gerlach, V.G., Teaching \& Media: A Systematic to Approach, New Jersey: Prentice Hall, 1980.

Frye, H. R., Techniques for Producing Visual Instructional Media, $2^{\text {nd }}$ ed., New York: McGraw-hill Book Company, 1962.

Heinich, R., et al., Instructional media and the new technologies of learning. New Jersey: Prentice-Hall, Inc., 1996.

http://www.uncur.ac.id/animasi-multimedia-pembelajaran/diakses pada 10 September 2008 tentang animasi multimedia pembelajaran

http://www.uny.ac.id. Diakses pada 10 September tentang animasi dalam pembelajaran

http://proquest.umi.com/pqdweb/2000/journal/. diakses pada 30 Januari 2009 tentang media animasi dan media visual

http://www.cat.ilstu.edu/aditional/tips/new/active/php. Diakses tanggal10 juli 2009 tentang pembelajaran aktif

http://www.curriki.org/media-pembelajaran/html. Diakses pada 30 September 2008 tentang media pembelajaran

http://www.eduBechmark.com/metodologi-pembelajaran/. diakses 10 September 2008 tentang metodologi pembelajaran. Belajar lebih menyenangkan dengan animasi

http://www.pribtk.blog2.plaza.com/efektivitas-multimedia/html. Diakses pada 3o Januari 2009 tentang efektifitas multimedia dalam menunjang pembelajaran peserta didik

http://re-searchingines.com/1007arief4.html. Diakses 11 September 2009 tentang motivasi belajar

http://www.ialf.edu/membuat-media-pembelajaran-interaktif-dengan-piranti-lunakpresentasi/. Diakses pada 30 Januari 2009 tentang membuat media pembelajaran interaktif dengan piranti lunak presentasi 
http://www.kurtek.ac.id. diakses 30 Januari 2009 tentang prinsip multimedia

Jarolimek, J., Social Studies in Elementary Education, New York: Mac Millan Publishing Company, 1986.

Kemp, J.E., \& Dayton, D. K., Planning and Producing Instructional Media, New York: Harper \& Row Publisher Combridge, 1985.

Merril P. F., Computer in Education. $3^{\text {rd }}$ Ed. Boston: Allin \& Bacon, A Simon \& Schuster Company Needham Heights, Mass, 1996.

Newby, T.J. et.al., Instructional Technology for Teaching and Learning: Designing Instruction, Integrating Computers, and Using Media, New Jersey: Prentice Hall, 2000.

Oemar Hamalik, Media pendidikan. Bandung: Citra Aditya Bakti, 1994.

Peraturan Menteri Pendidikan Nasional No 16, Standar kualifikasi akademik dan kompetensi guru. Jakarta: BSNP Depdiknas, 2007.

Peraturan Menteri Pendidikan Nasional No. 23, Standar Kompetensi Lulusan, Jakarta: BSNP Depdiknas, 2006.

Ratna W. Dahar, Teori-teori belajar. Jakarta: Depdikbud, 1988.

Santrock. J. W., Educational Psychology $3^{\text {rd }}$ ed., New York: Mc Graw Hill International Edition, 2008.

Santrock, J.W. Life-span Development, Juda Damanik, Achmad Chusairi (terj.). Herman Sinaga, Yati Sumiharti (eds), Jakarta: Erlangga, 2002.

Syaiful Bahri Djamarah \& Aswan Zain, Strategi Belajar Mengajar, Jakarta: Rineka Cipta, 1995.

Tan Seng Chee, Teaching and Learning with Technology: an Asia Pasific Perspective. Singapore: Prentice Hall, 2003. 
